\title{
Mapping COVID-19 related research from Saudi Arabia, a scoping review
}

\author{
Between reality and dreams
}

Ibrahim Almaghlouth, MBBS, MSc, Tahera Islam, MD, Nurah Alamro, MD, MPH, Abdulrahman Alsultan, MD, FAAP, Assim Alfadda, FRCPC, FACP, Saleh Al-muhsen, MBA, FRCP, Abeer Almasry, MD, PhD, Majid A. Almadi, MSc, FRCPC, Ahmad Hersi, MSc, MBA, Ahmed BaHammam, FRCPC, FCCP.



Objectives: To map research production by Saudiaffiliated investigators in order to identify areas of strength and weakness.

Method: We followed the Arksey and O'Malley (2005) framework. Medline and Cochrane databases were searched with a focus on identifying articles related to COVID-19 and Saudi Arabia following the PRISMA protocol. The study was conducted at King Saud University, Riyadh, Saudi Arabia between March and May 2020.

Results: A total of 53 articles were ultimately included. Most of the research production from Saudi Arabia was opinion and narrative reviews related to the clinicopathological features of COVID-19 as well as control and prevention of virus spread.
Conclusion: The results of this scoping review identify a relative deficiency in original research, which requires further investigation.

Keywords: scoping review, COVID-19, knowledge gap, research production, Saudi Arabia

Saudi Med J 2020; Vol. 41 (8): 791-801 doi: 10.15537/smj.2020.8.25163

From the Department of Medicine, College of Medicine (Almaghlouth, Alfadda, Almadi, BaHammam), from the College of Medicine Research Center (Almaghlouth, Islam, Alsultan, Alfadda, Almadi, Hersi, BaHammam), from Immunology Research Center (Almaghlouth, Alfadda, Al-muhsen, Almasry), College of Medicine, from the Department of Family and Community Medicine (Alamro, Hersi), from the Obesity Research Center and the Department of Internal Medicine (Alsultan, Alfadda), from the Department of Pediatrics (Al-mubsen), from the Department of Cardiac Sciences (Hersi), College of Medicine, and from Prince Nayef Health Sciences Research Center (BaHammam), King Saud University, Riyadh, Kingdom of Saudi Arabia.

Received 12th May 2020. 10th June 2020.

Address correspondence and reprint request to: Dr. Ibrahim Almaghlouth, Department of Medicine, College of Medicine, King Saud University, Riyadh, Kingdom of Saudi Arabia. E-mail: ialmaghlouth@ksu.edu.sa ORCID ID: https://orcid.org/0000-0001-9440-0280

The first case of the COVID-19 virus was reported 1 by Chinese authorities in Wuhan on December 31, 2019. As it continue to spread, defying borders of countries and continents, the World Health Organization (WHO) declared a pandemic on March 11, 2020. ${ }^{1,2}$ As of May 5, 2020, 3,600,1063 people have contracted COVID-19, with 251,898 deaths, and the disease has been transmitted to 212 countries and territories worldwide. After just a month, 
the total number of patients had reached 30,251 (May 5, 2020) and 200 deaths. ${ }^{3,4}$

COVID-19 is a non-segmented betacoronavirus comprise of positive-sense single-stranded ribonucleic acid surrounded by a phospholipid bilayer viral envelope. $^{5-7}$ The exact zoonotic host remains to be identified, although bats might be involved. ${ }^{8,9}$ The case history of the first several cases in Wuhan linked them to the local live animal and seafood market. ${ }^{10}$ The person-to-person transmission of the virus mainly occurs via droplet, close contact of healthy persons to infected individuals (examples, talking, sneezing, coughing), and indirect contact with contaminated objects (examples, stethoscope, thermometer) or surfaces. ${ }^{11,12}$ COVID-19 is a highly contagious disease with a relatively high reproductive number (R0) (examples the average number of new infections caused by an infectious person in a totally uninfected population) of 2-3.5. ${ }^{10,13,14}$ The fast-spreading nature of the disease threatens to inundate health care systems worldwide. The disease spectrum of COVID-19 varies from asymptomatic carriers to life-threatening conditions, including myocarditis and acute respiratory distress syndrome (ARDS). ${ }^{5,15}$ The fast-spreading nature of the disease threatens to inundate health care systems worldwide.

The COVID-19 pandemic has created a complex humanitarian emergency; the overwhelmingly high cost of the response is taking a toll on the economy and health facilities of even the developed countries. ${ }^{16}$ This leaves academic institutions with a major responsibility to investigate the disease from a holistic prospective, including asymmetric severity distribution, mortality, and spread among different geographical distribution, while avoiding duplicating research topics. Furthermore, national research institutes should focus on the most pressing issues related to COVID-19 on the national level. Hence, we aim in this scoping review to map research publications pertaining to COVID-19 research in Saudi Arabian institutions in order to guide research policies and priorities in the kingdom.

Methods. We formulated our scoping review using the scoping review methodological framework proposed by Arksey and $\mathrm{O}^{\prime}$ Malley ${ }^{17}$ and also following the recent scoping review publication by Tricco et al. ${ }^{18}$ We mapped

Disclosure. Authors have no conflict of interests, and the work was not supported or funded by any drug company. the literature by following 5 key phases: i) identifying the research question; ii) identifying literature relevant to COVID-19 in Saudi Arabia; iii) selecting only those studies; iv) charting the data from the articles; and v) collating, summarizing, and reporting results. We did not consult any stakeholders. The study was conducted at the College of Medicine and Research Center, King Saud University, Riyadh, Saudi Arabia, from March to May 2020.

Research questions. This scoping review was guided by the following questions: "What type of research was carried out in Saudi Arabian institutions on COVID-19? What aspects of the disease and its impact were investigated?"

Data sources and search strategy. A comprehensive electronic database search was performed using PubMed, Ovid-Medline (1946-present), EBM Reviews, and Cochrane databases by an author and another independent reviewer individually. No language, date, or type of article restrictions were applied. Gray literature was not included. Search criteria were developed to capture articles that addressed the literature relevant to research regarding COVID-19 from Saudi Arabian institutions. Search terms used were COVID-19 and Saudi Arabia. Two reviewers independently reviewed extracted articles. Conflicts were resolved by agreement, and in case of dispute a third reviewer was responsible for the decision.

Citation management. Duplicate citations were initially removed in Ovid for citations from Medline, the Editorial Board Member (EMB) reviews, and Cochrane databases.

All studies related to COVID-19 that were conducted in the institutions of Saudi Arabia, both local and in collaboration with scientists from other countries, authored by a Saudi researcher or a non-Saudi researcher representing a Saudi institution were eligible for inclusion. Both published and accepted articles in press that were already published online were also included.

Title and abstract relevance screening. The titles and abstracts of the identified articles were first examined by one author and cross-checked by another author for relevance and inclusion criteria. The reason for omitting each of the excluded papers was recorded.

For selected papers, data were abstracted and charted in Microsoft Excel 2010 using the following categorization: title, first author, Saudi author (if the first author is not Saudi and another coauthor is Saudi), name of the Saudi Arabian institution involved in the study, year and month of the study (in case of published studies), articles in press (for published online articles), 
national or collaborative international, name of the countries in case of multinational studies, type of study (narrative, review/opinion, letter to editor/ correspondence, comment/opinion/editorial, short communication, systematic review, guidelines and systematic review, observational including case reports, case series, cohort, cross-sectional, experimental, survey, modeling/epidemiological, and basic science), aim and objectives of the study, and keywords.

Results. Literature search. The initial search in different databases yielded 175 citations, of which 88 were duplicate and deleted. After rescreening, 34 articles did not meet the eligibility criteria; 27 papers mention Saudi Arabia in their abstract or text only as reference, but the researches were conducted in other countries and 7 papers were related to other coronaviruses and had mentioned COVID-19 in their abstract or text. Ultimately, 53 papers met the inclusion criteria. The study selection process is presented in full detail as a Preferred Reporting Items for Systematic Reviews and Meta-Analyses (PRISMA) flow diagram in Figure 1.

Characteristics of sources of evidence. Among the included 53 papers, authors of 43 articles were Saudi nationals; in 10 articles (19\%), Saudi nationals were first authors. Ten articles out of the 53 were authored by non-Saudi nationals affiliated with Saudi institutions. Most of the papers were coauthored by investigators under the affiliation of Johns Hopkins Aramco Healthcare, Dhahran (20 articles; 38\%) and King Saud Medical City, Alfaisal University, Riyadh (16 articles; $30 \%)$. Table 1 presents the study characteristics of the included studies.

All the participating hospitals are listed in Table 2. All the papers were either published or accepted in 2020. Most of the papers $(n=33 ; 62 \%)$ were accepted and published online ahead of print. The majority of the studies $(38 ; 72 \%)$ were conducted in collaboration with scientists from other countries. The names of the countries are listed in Table 3.

Topics and themes of identified studies. A total of 15 studies (28\%) focused on control and prevention of COVID-19, investigating the importance of preventing mass gatherings, including Hajj and Umrah. Three of the $15 \mathrm{control} /$ prevention articles outlined measures to be taken during various surgeries, including dental surgery. The clinicopathological features of COVID-19 (Figure 2) were described by 15 studies (28\%). Six of the clinicopathological studies included discussion on the management of the infection. Nine papers (17\%) focused on the virology and genomics. One paper investigated the mechanism of action of various drugs
Table 1 - General characteristics of studies meeting eligibility criteria.

\begin{tabular}{|c|c|}
\hline Characteristics & n (\%) \\
\hline \multicolumn{2}{|l|}{ Publication type } \\
\hline Experimental studies & $2(3.7)$ \\
\hline Survey & $1 \quad(1.8)$ \\
\hline Reviews & $13(24.5)$ \\
\hline Systematic review & $2(3.8)$ \\
\hline Editorials/expert opinions & $15(28.3)$ \\
\hline Guideline & $2(3.8)$ \\
\hline Letter to editor/correspondence & $11(20.8)$ \\
\hline Building model & $2(3.8)$ \\
\hline Basic Science & $4(7.5)$ \\
\hline Short communication & $2(3.8)$ \\
\hline \multicolumn{2}{|l|}{ Authors } \\
\hline First authors from Saudi Arabia & $10(18.9)$ \\
\hline Studies with coauthors from Saudi Arabia & $43(81.1)$ \\
\hline \multicolumn{2}{|l|}{ Institutional affiliation } \\
\hline Johns Hopkins Aramco Healthcare, Dhahran & $20(37.7)$ \\
\hline King Saud Medical City & $16(30.2)$ \\
\hline Alfaisal University & $16(30.2)$ \\
\hline University of Aljouf & $3(5.7)$ \\
\hline King Saud bin Abdulaziz University for Health Sciences & $6(11.3)$ \\
\hline King Abdulaziz University, Jeddah & $6(11.3)$ \\
\hline King Saud University & $5(9.4)$ \\
\hline King Faisal University, Al-Ahsa, Hofuf & $4(7.5)$ \\
\hline King Faisal Specialist Hospital \& Research Centre & $1(1.9)$ \\
\hline Other each having 1 & $14(26.4)$ \\
\hline \multicolumn{2}{|l|}{ Studied topics } \\
\hline Clinicopathologic & $15(28.3)$ \\
\hline Control and prevention & $15(28.3)$ \\
\hline Virology and genome & $9 \quad(17)$ \\
\hline Medical management & $6(11.3)$ \\
\hline Epidemiology & $5(9.4)$ \\
\hline Radiology & $5(9.4)$ \\
\hline Economic impact & $1 \quad(1.9)$ \\
\hline
\end{tabular}

on the viral genome. ${ }^{19}$ Surgeons from the city of Al Madinah Al Munawarah, Saudi Arabia were involved in a huge multinational survey of 47 hand surgeons working in 34 countries, including the United States, China, and Canada, that focused on the different measures adopted to combat the pandemic. ${ }^{20}$ The effect of different drugs on humans were examined in only one clinical trial. Four different treatment options were administered in a multinational randomized trial: antibiotics, antiviral therapy for influenza, host immunomodulation with extended macrolide therapy, and alternative corticosteroid regimens, representing 240 treatment regimens. ${ }^{21}$

Types of studies. Approximately one third of the papers are comment/opinion/editorial $(n=15 ; 28 \%)$, one fourth are review articles $(n=13 ; 25 \%)$, and one fifth letters to the editor/correspondence ( $n=11 ; 21 \%)$. Figure 3 depicts the types of articles included in this 



Figure 1 - Preferred Reporting Items for Systematic Reviews and Meta-Analyses (PRISMA) 2009 flow diagram

Table 2 - Participating institutions of the included studies.

\begin{tabular}{l}
\hline Institutions \\
\hline Johns Hopkins Aramco Healthcare, Dhahran \\
University of Aljouf \\
King Saud Medical City \\
King Saud bin Abdulaziz University for Health Sciences \\
King Faisal Specialist Hospital \& Research Centre \\
KingSaud University \\
Alfaisal University \\
King Abdulaziz University \\
King Faisal University, Al-Ahsa \\
King Abdulaziz Medical City \\
University of Bisha \\
Al Ahsa Veterinary Diagnostic Laboratory \\
Imam Abdulrahman Bin Faisal University, Dammam \\
Saudi Field Epidemiology, Riyadh, Training Program \\
Prince Sultan Military Medical City \\
Riyadh Elm University \\
National Guard Hospital Medina \\
Qatif Central Hospital \\
Jazan University \\
Majmaah University \\
King Abdullah Medical City \\
The Global Centre for Mass Gatherings Medicine, Ministry of Health
\end{tabular}

review. A similar trend was noted in the publications where the first authors were Saudi nationals. Three out of $10(30 \%)$ were in the category of comment/ opinion/editorial and $2(20 \%)$ were review articles. The remainder were categorized as basic science, modeling, and short communications.

Research priorities. To address the gap between the research priorities set by the WHO blueprint and the papers published by scientists affiliated with Saudi institutions, we categorized the papers according to the blueprint, looking at the themes and aims of the studies (Table 4). The table demonstrates the paucity of experimental research with clinical outcomes and vaccine-related research. It also highlights the lack of research on animals and environmental sources of virus origin as well as the human-animal interface.

Discussion. This scoping review of research publication related to COVID-19 in Saudi Arabia identified 53 articles (Table 5). Most of the included studies focused on control and prevention and on the clinicopathological aspects of the disease. The articles focused on the importance of and ways to prevent 
COVID-19 research in Saudi Arabia ... Almaghlouth et al

Table 3 - Countries in collaboration with Saudi Arabia for included studies.

\begin{tabular}{llll}
\hline Australia & Honduras & Netherlands & Spain \\
Afghanistan & Hong Kong & Nepal & Switzerland \\
Argentina & Iran & Norway & Turkey \\
Bolivia & Italy & New Zealand & Taiwan \\
Brazil & India & Oman & Tunisia \\
Belgium & Indonesia & Panama & United Arab Emirates \\
Canada & Israel & Pakistan & United Kingdom \\
Cameroon & Iraq & Peru & United States of America \\
China & Ireland & Portugal & Venezuela \\
Chile & Japan & Qatar & Yemen \\
Colombia & Jordan & Republic of Congo & Zambia \\
Denmark & Korea & Russia & \\
Egypt & Mexico & Sudan & \\
France & Mali & South Africa & \\
Germany & Morocco & Singapore & \\
\hline
\end{tabular}

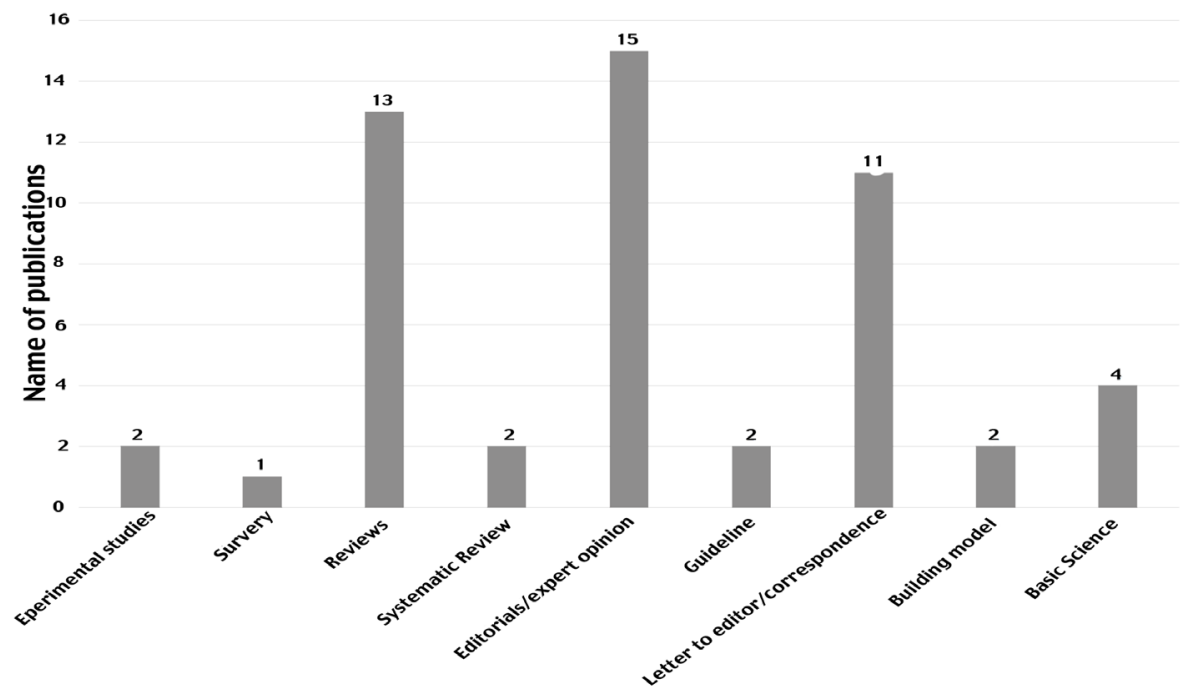

Figure 2 - Identified topics and purpose of disease.

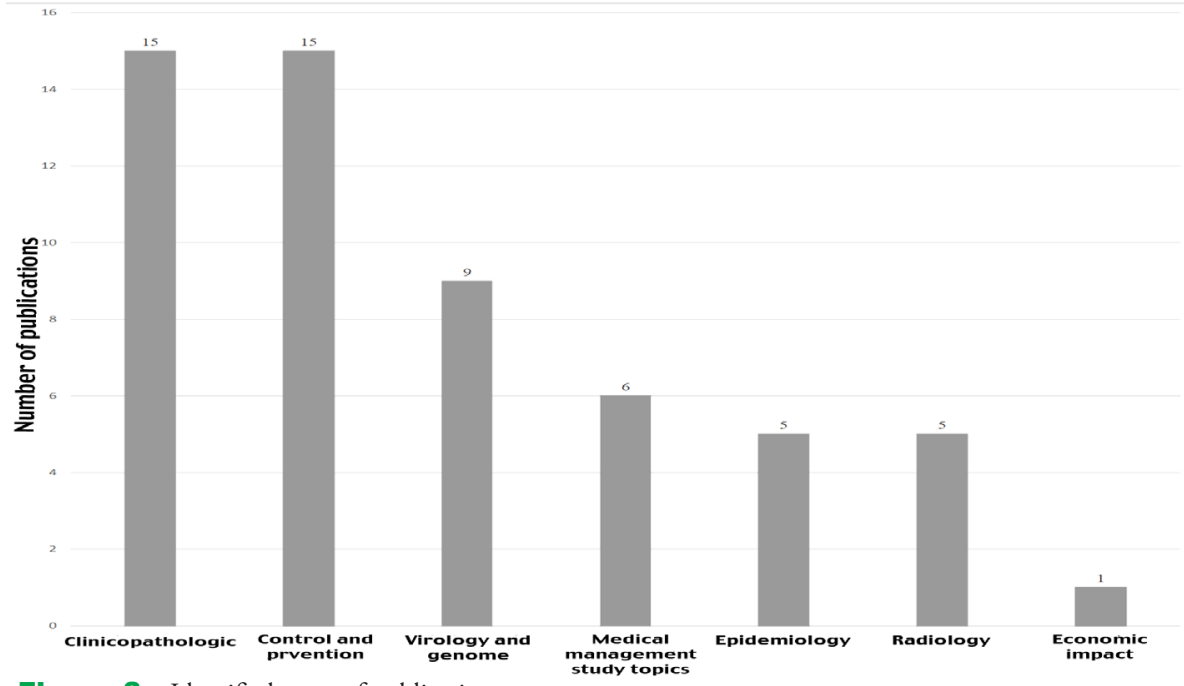

Figure 3 - Identified types of publications. 
Table 4 - Research themes of the included articles according to the WHO research priorities for COVID-19.

\begin{tabular}{|c|c|}
\hline Research Priorities & $\begin{array}{l}\text { Number } \\
\text { of articles }\end{array}$ \\
\hline \multicolumn{2}{|l|}{ Virus: natural history, transmission and diagnostics } \\
\hline Understand the natural history of the virus and shedding of it from an infected person & 1 \\
\hline Support implementation of diagnostics and products to improve clinical processes & 4 \\
\hline Develop disease models, including animal models for infection, disease and transmission & 7 \\
\hline \multicolumn{2}{|l|}{ Develop tools and studies to monitor phenotypic change and potential adaptation of the virus } \\
\hline Better understand the immune response and immunity & 0 \\
\hline \multicolumn{2}{|l|}{ Animal and environmental research on the virus origin, and management measures at the human-animal interface } \\
\hline Identify animal host(s) and any evidence of continued spill-over to humans & 1 \\
\hline Understand the socioeconomic and behavioral risk factors for this spill-over & 1 \\
\hline Design and test sustainable risk reduction strategies & 0 \\
\hline \multicolumn{2}{|l|}{ Epidemiological studies } \\
\hline $\begin{array}{l}\text { Understand the transmission dynamics of the virus, including the basic reproductive number, incubation period, serial interval, modes } \\
\text { of transmission and environmental factors }\end{array}$ & 8 \\
\hline Define the severity of disease, including risk of fatality among symptomatic hospitalized patients, and high-risk patient groups & 3 \\
\hline Understand susceptibility of populations & 2 \\
\hline Identify what public health mitigation measures could be effective for control & 16 \\
\hline \multicolumn{2}{|l|}{ Clinical characterization and management } \\
\hline $\begin{array}{l}\text { Define the natural history of disease to inform clinical care, public health interventions, infection prevention control, transmission, and } \\
\text { clinical trials }\end{array}$ & 3 \\
\hline Develop a core clinical outcome set to maximize usability of data across a range of trials & 0 \\
\hline $\begin{array}{l}\text { Determine adjunctive and supportive interventions that can improve the clinical outcomes of infected patients (examples, steroids, high } \\
\text { flow oxygen) }\end{array}$ & 1 \\
\hline \multicolumn{2}{|l|}{ Infection prevention and control, including health care workers' protection } \\
\hline Understand effectiveness of movement control strategies to prevent secondary transmission in health care and community settings & 5 \\
\hline $\begin{array}{l}\text { Optimize the effectiveness of personal protective equipment (PPE) and its usefulness to reduce risk of transmission in health care and } \\
\text { community settings }\end{array}$ & 0 \\
\hline Minimize the role of the environment in transmission & 3 \\
\hline Candidate therapeutics (research and development) & 0 \\
\hline \multicolumn{2}{|l|}{ Develop animal models and standardize challenge studies } \\
\hline \multicolumn{2}{|l|}{ Develop prophylaxis clinical studies and prioritize in healthcare workers } \\
\hline Candidate vaccines $R \& D$ & 0 \\
\hline \multicolumn{2}{|l|}{ Optimize clinical trial design, including for Phase III/ prioritized candidates for testing } \\
\hline \multicolumn{2}{|l|}{ Understand approaches to evaluate risk for enhanced disease after vaccination } \\
\hline \multicolumn{2}{|l|}{$\begin{array}{l}\text { Develop assays to evaluate vaccine immune response and process development for vaccines, alongside suitable animal models (in } \\
\text { conjunction with therapeutics) }\end{array}$} \\
\hline Ethical considerations for research & 0 \\
\hline \multicolumn{2}{|l|}{ Articulate and translate existing ethical principles and standards to salient issues in COVID-2019 } \\
\hline \multicolumn{2}{|l|}{ Embed ethics across all thematic areas, engage with novel ethical issues that arise and coordinate to minimize duplication of oversight } \\
\hline
\end{tabular}

community transmission, which included plans for preventing community gatherings such as Hajj and Umrah along with the Tokyo Olympics. ${ }^{30}$ Furthermore, issues related to the importance and prevention of cross infection to healthcare workers or different surgical and medical departments were reviewed. A significant number of studies focused on viral genomics and its implication on drug discovery including the potential use of existing drugs to target the virus. ${ }^{19}$

Almost all of the articles were narrative, focusing on reported views and experiences. Only 2 were experimental; one of the 2 is a large multicentral, multinational clinical trial, investigating treatment modalities of community-acquired pneumonia and
COVID19. The study was initially launched in European countries and later expanded to Saudi Arabia. The findings of this scoping review highlight the collaborative nature of most of the research conducted by Saudi scholars in relation to COVID-19. However, the limited number of Saudi investigator-initiated studies, especially with respect to experimental research, is concerning. These findings highlight the gaps in COVID-19 related research from Saudi research institutes. First, the number of experimental studies focused on new treatment options were very low. Second, the economic impact on specific health resources in Saudi Arabia was not investigated. Moreover, epidemiological studies focused on disease 
Table 5 - The types of included studies.

\begin{tabular}{|c|c|c|}
\hline Author(s) & Study title & Types of Articles \\
\hline Alhazzani et $\mathrm{al}^{22}$ & $\begin{array}{l}\text { Surviving sepsis campaign: guidelines on the management of critically ill adults with Coronavirus Disease } 2019 \\
\text { (COVID-19) }\end{array}$ & Guideline \\
\hline Elfiky $^{19}$ & Anti-HCV, nucleotide inhibitors, repurposing against COVID-19 & Experimental \\
\hline Al-Tawfiq ${ }^{23}$ & Asymptomatic Coronavirus infection: MERS-CoV and SARS-CoV-2 (COVID-19) & Letter to the Editor \\
\hline $\mathrm{Al}$-qaness et $\mathrm{al}^{24}$ & Optimization Method for Forecasting Confirmed Cases of COVID-19 in China & Building model \\
\hline $\mathrm{Xu}$ et $\mathrm{al}^{25}$ & Systematic comparison of 2 animal-to-human transmitted human Coronaviruses: SARS-CoV-2 and SARS-CoV & Systematic Review \\
\hline Bedford et $\mathrm{al}^{26}$ & COVID-19: towards controlling of a pandemic & Opinion \\
\hline Arabi et $\mathrm{al}^{27}$ & COVID-19: a novel coronavirus and a novel challenge for critical care & Opinion \\
\hline Nasir et $\mathrm{al}^{28}$ & The role of emergency radiology in COVID-19: From preparedness to diagnosis & Review \\
\hline Sah et $\mathrm{al}^{29}$ & Complete genome sequence of a 2019 Novel Coronavirus (SARS-CoV-2) strain isolated in Nepal & $\begin{array}{l}\text { Basic science/short } \\
\text { communication }\end{array}$ \\
\hline Gautret et $\mathrm{al}^{30}$ & COVID 19: Will the 2020 Hajj pilgrimage and Tokyo Olympic Games be cancelled? & Letter to the editor \\
\hline $\begin{array}{l}\text { Rodriguez-Morales } \\
\text { et } \mathrm{al}^{31}\end{array}$ & History is repeating itself: probable zoonotic spillover as the cause of the 2019 Novel Coronavirus epidemic & Editorial \\
\hline Arab-Mazar et $\mathrm{al}^{32}$ & Mapping the incidence of the COVID-19 hotspot in Iran - implications for travellers & Letter to the editor \\
\hline Kandeel et $\mathrm{al}^{33}$ & $\begin{array}{l}\text { From SARS and MERS CoVs to SARS-CoV-2: moving toward more biased codon usage in viral structural and } \\
\text { nonstructural genes }\end{array}$ & Basic Science \\
\hline Meo et $\mathrm{al}^{34}$ & $\begin{array}{l}\text { Novel coronavirus 2019-nCoV: prevalence, biological and clinical characteristics comparison with SARS-CoV and } \\
\text { MERS-CoV }\end{array}$ & Review \\
\hline Farooq et $\mathrm{al}^{35}$ & COVID-19 outbreak and its monetary implications for dental practices, hospitals and healthcare workers & Letter to the editor \\
\hline Al-Tawfiq ${ }^{36}$ & Middle East Respiratory Syndrome Coronavirus (MERS-CoV) and COVID-19 infection during pregnancy & Letter to the editor \\
\hline Khurshid et $\mathrm{al}^{37}$ & Human saliva: non-invasive fluid for detecting novel Coronavirus (2019-nCoV) & Opinion \\
\hline Arabi et $\mathrm{al}^{38}$ & Critical care management of adults with mommunity-acquired severe respiratory viral infection & Review \\
\hline Ibrahim $^{39}$ & COVID-19 spike-host cell receptor GRP78 binding site prediction & Basic Science \\
\hline $\begin{array}{l}\text { Rodriguez-Morales } \\
\text { et } \mathrm{al}^{40}\end{array}$ & Clinical, laboratory and imaging features of COVID-19: A systematic review and meta-analysis & Systematic review \\
\hline AlNsour et $\mathrm{al}^{41}$ & $\begin{array}{l}\text { The role of the Global Health Development/Eastern Mediterranean Public Health Network and the Eastern } \\
\text { Mediterranean Field Epidemiology Training Programs in preparedness for COVID-19 }\end{array}$ & Opinion \\
\hline $\mathrm{Ralph}^{42}$ & $\begin{array}{l}2019-\mathrm{nCoV} \text { (Wuhan virus), a novel Coronavirus: human-to-human transmission, travel-related cases, and vaccine } \\
\text { readiness }\end{array}$ & Basic Science \\
\hline Al-Tawfiq ${ }^{43}$ & Viral loads of SARS-CoV, MERS-CoV, and SARS-CoV-2 in respiratory specimens: What have we learned? & Letter to the editor \\
\hline Ebrahim et $1^{44}$ & Covid-19 and community mitigation strategies in a pandemic & Opinion \\
\hline Ahmed et $\mathrm{al}^{45}$ & The cancellation of mass gatherings (MGs)? Decision making in the time of COVID-19 & Short communication \\
\hline Barry et $\mathrm{al}^{46}$ & COVID-19 in the shadows of MERS-CoV in the Kingdom of Saudi Arabia & Opinion \\
\hline Ebrahim et $\mathrm{al}^{47}$ & COVID-19 - the role of mass gatherings & Review \\
\hline Al-Tawfiq et $\mathrm{l}^{48}$ & Diagnosis of SARS-CoV-2 infection based on CT scan vs. RT-PCR: Reflecting on experience from MERS-CoV & Opinions \\
\hline Al-Tawfiq ${ }^{49}$ & Remdesivir as a possible therapeutic option for the COVID-19 & Letter to the editor \\
\hline Petersen et $\mathrm{al}^{50}$ & $\begin{array}{l}\text { Li Wenliang, a face to the frontline healthcare worker. The first doctor to notify the emergence of the SARS- } \\
\text { CoV-2, (COVID-19), outbreak }\end{array}$ & Editorial \\
\hline Ebrahim et $a^{51}$ & COVID-19: preparing for superspreader potential among Umrah pilgrims to Saudi Arabia & Correspondence \\
\hline Ebrahim et $\mathrm{al}^{52}$ & Saudi Arabia`s measures to curb the COVID-19 outbreak: temporary suspension of the Umrah pilgrimage & Opinion \\
\hline Zumla et $\mathrm{al}^{53}$ & Reducing mortality from 2019-nCoV: host-directed therapies should be an option & Correspondence \\
\hline Hui et $\mathrm{al}^{54}$ & $\begin{array}{l}\text { The continuing } 2019-\mathrm{nCoV} \text { epidemic threat of novel coronaviruses to global health - The latest } 2019 \text { novel } \\
\text { coronavirus outbreak in Wuhan, China }\end{array}$ & Editorial \\
\hline Hemida et $\mathrm{al}^{55}$ & The SARS-CoV-2 outbreak from a one health perspective & Review \\
\hline Islam et $\mathrm{al}^{56}$ & Emergence of deadly severe acute respiratory syndrome coronavirus-2 during 2019-2020 & Review \\
\hline Meo et $\mathrm{al}^{57}$ & $\begin{array}{l}\text { Biological and Epidemiological Trends in the Prevalence and Mortality due to Outbreaks of Novel Coronavirus } \\
\text { COVID-19 }\end{array}$ & Review \\
\hline Alharbi et $\mathrm{al}^{58}$ & Guidelines for dental care provision during the COVID-19 pandemic. & Guideline \\
\hline Ducournau et $\mathrm{al}^{20}$ & COVID-19: Initial experience of an international group of hand surgeons. & Survey \\
\hline Al-Tawfiq J et al ${ }^{59}$ & Super-spreading events and contribution to transmission of MERS, SARS, and COVID- 19. & Review \\
\hline Rabaan et $\mathrm{al}^{60}$ & SARS-CoV-2, SARS-CoV, and MERS-COV: A comparative overview & Review \\
\hline $\begin{array}{l}\text { Rodriguez-Morales A } \\
\text { et } \mathrm{al}^{61}\end{array}$ & Genomic epidemiology and its importance in the study of the COVID-19 pandemic. & Editorial \\
\hline Hasan et $\mathrm{al}^{62}$ & $\begin{array}{l}\text { A review on the cleavage priming of the spike protein on coronavirus by angiotensin converting enzyme- } 2 \\
\text { and furin. }\end{array}$ & Review \\
\hline Phua et $\mathrm{al}^{63}$ & $\begin{array}{l}\text { Intensive care management of coronavirus disease } \\
2019 \text { (COVID-19): challenges and recommendations. }\end{array}$ & Review \\
\hline Angus et $\mathrm{al}^{20}$ & $\begin{array}{l}\text { The randomized embedded multifactorial adaptive platform for community-acquired pneumonia (REMAP- } \\
\text { CAP) study: rationale and design. }\end{array}$ & Clinical trial \\
\hline Al-Tawfiq et al ${ }^{64}$ & COVID-19 in the Eastern Mediterranean Region and Saudi Arabia: prevention and therapeutic strategies & Review \\
\hline Kandeel et al ${ }^{65}$ & Virtual screening and repurposing of FDA approved drugs against COVID-19 main protease & Building model \\
\hline Mallineni et $\mathrm{al}^{66}$ & Coronavirus disease (COVID-19): Characteristics in children and considerations for dentists providing their care & Editorial \\
\hline Memishet $\mathrm{al}^{67}$ & No time for dilemma: mass gatherings must be suspended. & Correspondence \\
\hline Whiteside et $\mathrm{al}^{68}$ & Redesigning emergency department operations amidst a viral pandemic & Review \\
\hline Yezli et $\mathrm{al}^{69}$ & $\begin{array}{l}\text { COVID-19 social distancing in the Kingdom of Saudi Arabia: Bold measures in the face of political, economic, } \\
\text { social and religious challenges }\end{array}$ & Short communication \\
\hline Atique et $\mathrm{al}^{70}$ & Hajj in the time of COVID-19 & Letter to the editor \\
\hline Petersen et $\mathrm{al}^{71}$ & & Editorial \\
\hline
\end{tabular}


transmission or modeling of important outcomes such as health resources utilization were lacking. Furthermore, the current published research seems to be discordant from the WHO research and development blueprint for epidemic research that was established in 2015 and updated in 2017 by international experts. ${ }^{72}$ The blueprint was developed to ensure research preparedness during outbreak crises with a special focus on vaccine development, diagnostic testing, and therapeutic testing. ${ }^{74}$ While it is possible that some of the national research projects are still ongoing and were not captured by the time we prepared this article, clearly, the current publications do not reflect strong national research preparedness to adequately address epidemics and pandemics.

This scoping review is useful in the context of fund allocation from the government through various institutions to support health care and COVID-19related research on a national and international level. Interestingly, if we examine previous efforts from the Saudi Ministry of Health in the era of the MERS-Cov epidemic, we can find a road map that addressed similar issues related to emerging infection research, particularly in the field of vaccine development. ${ }^{73}$ The international workshop hosted by the Saudi government called for a paradigm shift establish clear goals of public health interest that guide epidemic research. The government, represented by the Ministry of Health, and academic institutions, in collaboration with international stakeholders, including the WHO, should work together to achieve this goal. ${ }^{75}$ Unfortunately, most of the published research during this pandemic seems to stray from the previously addressed road map and instead focuses on opinions and narrative reviews rather than original research. This calls for careful and in-depth analysis to identify the factors contributing to the current state of research. The research gap related to COVID-19 identified by the WHO that needs to be addressed by the global community are: i) Understand the natural history of infection, identify animal host, infection and transmission of infection including asymptomatic infection and susceptible population. ii) Determine the most effective standard of care approach using data from China and other countries. iii) Research on adjunctive and supportive therapies. iv) Research on rapid point of care diagnostics. v) Clinical trials for development of vaccine and investigating therapeutics. This can be utilized for planning future research steps.

This scoping review also identifies that Saudi Arabia scholars' research is mainly focused on the pathogenesis of the COVID-19 infection and opinions related to viral control and prevention. This is important, since the priority of research at the level of funding agencies and even national strategy should take this into account in order to improve the knowledge gap in understudied and important fields such as epidemiological studies, diagnostic testing, immune response, genetic predisposition to sever phenotypes and experimental treatment interventions.

Study limitation. We did not search the gray literature or the EMBASE. Also this study did not capture unpublished ongoing research projects, particularly in areas of molecular and basic science, at the time of this manuscript preparation.

Finally, the aim of this scoping review was to map our COVID-19-related research on a national level in order to identify areas of strength and weakness. The results of our knowledge mapping should be followed by coordinated efforts from all stakeholders in our national health research, including the Ministry of Health, Ministry of Higher Education, academic and research institutes, National Institutes of Health, and the Center of Chronic Disease Prevention in order to identify a national strategy that invests in building capacities inspired by Saudi Vision 2030 and in alignment with the WHO epidemic research and development blueprint. In particular, we call for clear national strategy for health research that takes inconsideration emerging epidemics along with other public health priorities. We urge all national research institutes to identify research infrastructure capacity in order to maximize the utility of these infrastructures and help overcome their shortcomings. In addition, we suggest establishing national capacity for regular laboratory research materials through the investment in national companies for laboratory materials. Furthermore, we strongly encourage the investment in public health schools especially in leading national universities which are entailed to handle public health crises while provide guidance to the government in the most scientific and evidence-based approach.

In conclusion, this scoping review was a first step by the authors toward contributing to the development of a national COVID-19 pandemic research agenda for decision-makers concerned with the role of national health research in priority setting and resource allocation. Many decision-makers are seeking research support and guidance in moving forward during this critical time.

Ultimately, the intention of the national research activities should be to maximize the impact and usefulness of national public health interventions and policies. The decision-makers are facing the constraints 
of national COVID-19 pandemic research to inform priority setting and resource allocation decisions. The next step is to produce a national research framework for COVID-19 with specific research projects to address critical gaps identified through this scoping review. This can be achieved through collaboration between decision-makers and researchers with interests in this field.

Acknowledgment. The authors would also like to thank SCRIBENDI (www.scribendi.com) for English language editing.

\section{References}

1. World Health Organization. Statement on the second meeting of the International Health Regulations (2005) Emergency Committee regarding the outbreak of novel coronavirus (2019nCoV). [Updated 2020 January 30. Cited 2020 February 18]. Available from URL: https://www.who.int/news-room/ detail/30-01-2020-statement-on-the-second-meeting-ofthe-international-health-regulations-(2005)-emergencycommittee-regarding-the-outbreak-of-novel-coronavirus(2019-ncov)

2. World Health Organization. WHO Director-General's opening remarks at the media briefing on COVID-19 - 11 March 2020. [Updated 2020 March 11. Cited 2020 March 20.] Available from URL: https://www.who.int/dg/speeches/detail/whodirector-general-s-opening-remarks-at-the-media-briefing-oncovid-19--11-march-2020.

3. Worldmeter COVID-19 Coronavirus pandemic. [Updated 2020 June 18. Cited 2020]. Available from URL: https://www. worldometers.info/coronavirus/

4. Twitter. The Saudi Ministry of Health (MOH). [Updated 2020 May 6. Accessed 2020 May 6]. Available from URL: https:// twitter.com/SaudiMOH/status/1258014834890809345

5. Huang C, Wang Y, Li X, Ren L, Zhao J, Hu Y, et al. Clinical features of patients infected with 2019 novel coronavirus in Wuhan, China. Lancet 2020; 395: 497-506.

6. Wang D, Hu B, Hu C, Zhu F, Liu X, Zhang J, et al. Clinical characteristics of 138 hospitalized patients with 2019 novel coronavirus-infected pneumonia in Wuhan, China. JAMA 2020; 323: 1061-1069.

7. He F, Deng Y, Li W. Coronavirus Disease 2019 (COVID-19): what we know? J Med Virol 2020; 92: 719-725.

8. Zhou P, Yang XL, Wang XG, Hu B, Zhang L, Zhang W, et al. A pneumonia outbreak associated with a new coronavirus of probable bat origin. Nature 2020; 579: 270-273.

9. Center for Disease Control and Prevention. Coronavirus (2019-nCoV) situation summary. [Updated 2020 February 11. Cited 2020 April 22]. Available from URL: https:/www.cdc. gov/coronavirus/2019-ncov/summary.html.

10. Li Q, Guan X, Wu P, Wang X, Zhou L, Tong Y, et al. Early transmission dynamics in Wuhan, China, of Novel Coronavirusinfected pneumonia. N Engl J Med 2020; 382: 1199-1207.

11. Modes of transmission of virus causing COVID-19: implications for IPC precaution recommendations. Scientific brief. WHO. [Updated 2020 March 29. Cited 2020 April 22.] Available from URL: https://www.who.int/news-room/ commentaries/detail/modes-of-transmission-of-virus-causingcovid-19-implications-for-ipc-precaution-recommendations
12. Chan JF, Yuan S, Kok KH, To KK, Chu H, Yang J, et al. A familial cluster of pneumonia associated with the 2019 novel coronavirus indicating person-to-person transmission:a study of a family cluster. Lancet 2020; 395: 514-523.

13. World Health Organization. Report of the WHO-China Joint Mission on Coronavirus Disease 2019 (COVID-19). [Updated 2020 February. Accessed 2020 May 6]. https://www.who.int/ docs/default-source/coronaviruse/who-china-joint-mission-oncovid-19-final-report.pdf

14. Zhao S, Lin Q, Ran J, Musa SS, Yang G, Wang W, et al. Preliminary estimation of the basic reproduction number of novel coronavirus (2019-nCoV) in China, from 2019 to 2020: a data-driven analysis in the early phase of the outbreak. Int J Infect Dis 2020; 92: 214-217.

15. Chen N, Zhou M, Dong X, Qu J, Gong F, Han Y, et al. Epidemiological and clinical characteristics of 99 cases of 2019 novel coronavirus pneumonia in Wuhan, China: a descriptive study. Lancet 2020; 395: 507-513.

16. Haleem A, Javaid M, Vaishya R, Deshmukh SG. Areas of academic research with the impact of COVID-19 Am J Emerg Med 2020; 20: 30250-30253.

17. Arksey H, O’Malley L. Scoping studies: Towards a methodological framework. Int J Soc Res Methodol 2005; 8: 19-32.

18. Tricco AC, Lillie E, Zarin W, O’Brien K, Colquhoun H, Kastner $\mathrm{M}$, et al. A scoping review on the conduct and reporting of scoping reviews. BMC Med Res Methodol 2016; 16: 15.

19. Elfiky AA. Anti-HCV, nucleotide inhibitors, repurposing against COVID-19. Life Sci 2020; 248: 117477.

20. Ducournau F, Arianni M, Awwad S, Baur EM, Beaulieu JY, Bouloudhnine M, et al. COVID-19: Initial experience of an international group of hand surgeons. Hand Surg Rehabil 2020; 39: 159-166.

21. Angus DC, Berry S, Lewis RJ, Al-Beidh F, Arabi Y, van BentumPuijk W, et al. The Randomized Embedded Multifactorial Adaptive Platform for Community-acquired Pneumonia (REMAP-CAP) Study: Rationale and Design. Ann Am Thorac Soc 2020; 1-373.

22. Alhazzani W, Møller M, Arabi Y, Loeb M, Gong M, Fan E, et al. Surviving Sepsis Campaign: guidelines on the management of critically ill adults with Coronavirus Disease 2019 (COVID-19) Intensive Care Med 2020: 134.

23. Al-TawfiqJA. Asymptomatic coronavirus infection: MERS-CoV and SARS-CoV-2 (COVID-19). Travel Med Infect Dis 2020: 101608.

24. Al-Qaness MAA, Ewees AA, Fan H, Abd El Aziz M. Optimization method for forecasting confirmed cases of COVID-19 in China. J Clin Med 2020; 9: 674.

25. Xu J, Zhao S, Teng T, Abdalla AE, Zhu W, Xie L, et al. Systematic comparison of two animal-to-human transmitted human coronaviruses: SARS-CoV-2 and SARS-CoV. Viruses 2020; $12: 244$.

26. Bedford J, Enria D, Giesecke J, Heymann DL, Ihekweazu C, Kobinger G, et al. COVID-19: towards controlling of a pandemic. Lancet 2020; 395: 1015-1018.

27. Arabi YM, Murthy S, Webb S. COVID-19: a novel coronavirus and a novel challenge for critical care. Intensive Care Med 2020; 40: 833-836.

28. Nasir MU, Roberts J, Muller NL, Macri F, Mohammed MF, Akhlaghpoor $S$, et al. The role of emergency radiology in COVID-19: from preparedness to diagnosis. Can Assoc Radiol J 2020: 846537120916419 . 
29. Sah R, Rodriguez-Morales AJ, Jha R, Chu DKW, Gu H, Peiris M, et al. Complete Genome Sequence of a 2019 Novel Coronavirus (SARS-CoV-2) Strain Isolated in Nepal. Microbiol Resour Announc. 2020; 9: e00169-e00120.

30. Gautret P, Al-Tawfiq JA, Hoang VT. COVID 19: Will the 2020 Hajj pilgrimage and Tokyo Olympic Games be cancelled? Travel Med Infect Dis 2020; 34: 101622.

31. Rodriguez-Morales AJ, Bonilla-Aldana DK, Balbin-Ramon GJ, Rabaan AA, Sah R, Paniz-Mondolfi A et al. History is repeating itself: probable zoonotic spillover as the cause of the 2019 Novel Coronavirus Epidemic. Infez Med 2020; 28: 3-5.

32. Arab-Mazar Z, Sah R, Rabaan AA, Dhama K, RodriguezMorales AJ. Mapping the incidence of the COVID-19 hotspot in Iran - implications for travellers. Travel Med Infect Dis 2020: 34: 101630.

33. Kandeel M, Ibrahim A, Fayez M, Al-Nazawi M. From SARS and MERS CoVs to SARS-CoV-2: Moving toward more biased codon usage in viral structural and nonstructural genes. $J$ Med Virol 2020; 92: 660-666.

34. Meo SA, Alhowikan AM, Al-Khlaiwi T, Meo IM, Halepoto DM, Iqbal $\mathrm{M}$ et al. Novel coronavirus 2019-nCoV: prevalence, biological and clinical characteristics comparison with SARS-CoV and MERS-CoV. Eur Rev Med Pharmacol Sci 2020; 24: 2012-2019.

35. Farooq I, Ali S.COVID-19 outbreak and its monetary implications for dental practices, hospitals and healthcare workers. Postgrad Med J 2020; 137781.

36. Al-Tawfiq JA. Middle East Respiratory Syndrome Coronavirus (MERS-CoV) and COVID-19 infection during pregnancy. Travel Med Infect Dis 2020: 101641.

37. Khurshid Z, Asiri FYI, Al Wadaani H. Human saliva: noninvasive fluid for detecting Novel Coronavirus (2019-nCoV). Int J Environ Res Public Health 2020; 17: 2225.

38. Arabi YM, Fowler R, Hayden FG. Critical care management of adults with community-acquired severe respiratory viral infection. Intensive Care Med 2020; 46: 315-328.

39. Ibrahim IM, Abdelmalek DH, Elshahat ME, Elfiky AA. COVID-19 spike-host cell receptor GRP78 binding site prediction. J Infect 2020; 80: 554-562.

40. Rodriguez-Morales AJ, Cardona-Ospina JA, Gutiérrez-Ocampo E, Villamizar-Peña R, Holguin-Rivera Y, Escalera-Antezana JP et al. Clinical, laboratory and imaging features of COVID-19: A systematic review and meta-analysis. Latin American Network of Coronavirus Disease 2019-COVID-19 research (LANCOVID-19). Travel Med Infect Dis 2020: 34: 101623.

41. Al Nsour M, Bashier H, Al Serouri A, Malik E, Khader Y, Saeed K, et al. The role of the Global Health Development/ Eastern Mediterranean Public Health Network and the Eastern Mediterranean Field Epidemiology Training Programs in preparedness for COVID-19. JMIR Public Health Surveill 2020; 6: e18503.

42. Ralph R, Lew J, Zeng T, Francis M, Xue B, Roux M, et al. 2019-nCoV (Wuhan virus), a novel Coronavirus: human-tohuman transmission, travel-related cases, and vaccine readiness. J Infect Dev Ctries 2020; 14: 3-17.

43. Al-Tawfiq JA. Viral loads of SARS-CoV, MERS-CoV and SARS-CoV-2 in respiratory specimens: What have we learned? Travel Med Infect Dis 2020: 101629.

44. Ebrahim SH, Ahmed QA, Gozzer E, Schlagenhauf P, Memish ZA. Covid-19 and community mitigation strategies in a pandemic. BMJ 2020; 368: m1066.
45. Ahmed QA, Memish ZA. The cancellation of mass gatherings (MGs)? Decision making in the time of COVID-19. Travel Med Infect Dis 2020: 34: 101631.

46. Barry M, Al Amri M, Memish ZA. COVID-19 in the Shadows of MERS-CoV in the Kingdom of Saudi Arabia. J Epidemiol Glob Health 2020; 10: 1-3.

47. Ebrahim SH, Memish ZA. COVID-19 - the role of mass gatherings. Travel Med Infect Dis 2020; 34: 101617.

48. Al-Tawfiq JA, Memish ZA. Diagnosis of SARS-CoV-2 infection based on CT scan vs. RT-PCR: reflecting on experience from MERS-CoV. J Hosp Infect 2020; 105: 154-155.

49. Al-Tawfiq JA, Al-Homoud AH, Memish ZA. Remdesivir as a possible therapeutic option for the COVID-19. Travel Med Infect Dis 2020; 34: 101615.

50. Petersen E, Hui D, Hamer DH, Blumberg L, Madoff LC, Pollack M, et al. Li Wenliang, a face to the frontline healthcare worker. The first doctor to notify the emergence of the SARS-CoV-2, (COVID-19), outbreak. Int J Infect Dis 2020; 93: 205-207.

51. Ebrahim SH, Memish ZA. COVID-19: preparing for superspreader potential among Umrah pilgrims to Saudi Arabia. Lancet 2020; 395: e48.

52. Ebrahim SH, Memish ZA. Saudi Arabia`s measures to curb the COVID-19 outbreak: temporary suspension of the Umrah pilgrimage. J Travel Med 2020. pii: taaa029.

53. Zumla A, Hui DS, Azhar EI, Memish ZA, Maeurer M. Reducing mortality from 2019-nCoV: host-directed therapies should be an option. Lancet 2020; 395: e35-e36.

54. Hui DS, I Azhar E, Madani TA, Ntoumi F, Kock R, Dar $\mathrm{O}$, et al. The continuing 2019-nCoV epidemic threat of novel coronaviruses to global health - The latest 2019 novel coronavirus outbreak in Wuhan, China. Int J Infect Dis. 2020;91:264-266.

55. Hemida MG, Ba Abduallah MM. The SARS-CoV- 2 outbreak from a one health perspective. One Health 2020: 100127.

56. Islam A, Ahmed A, Naqvi IH, Parveen S. Emergence of deadly severe acute respiratory syndrome coronavirus-2 during 2019-2020. Virusdisease 2020: 1-9.

57. Meo SA, Al-Khlaiwi T, Usmani AM, Meo AS, Klonoff DC, Hoang TD. Biological and epidemiological trends in the prevalence and mortality due to outbreaks of Novel Coronavirus COVID-19. J King Saud Univ Sci 2020.

58. Alharbi A, Alharbi S, Alqaidi S. Guidelines for dental care provision during the COVID-19 pandemic. Saudi Dent J 2020; 32: 181-186.

59. Al-Tawfiq JA, Rodriguez-Morales AJ. Super-spreading events and contribution to transmission of MERS, SARS, and COVID-19. J Hosp Infect 2020; 105: 111-112.

60. Rabaan AA, Al-Ahmed SH, Haque S, Sah R, Tiwari R, Malik YS et al. SARS-CoV-2, SARS-CoV, and MERS-COV: A comparative overview. Infez Med 2020; 28: 174-184.

61. Rodriguez-Morales AJ, Balbin-Ramon GJ, Rabaan AA, Sah R, Dhama K, Paniz-Mondolfi A et al. Genomic epidemiology and its importance in the study of the COVID-19 pandemic. Infez Med 2020; 28: 139-142.

63. Hasan A, Paray BA, Hussain A, Qadir FA, Attar F, Aziz FM et al. A review on the cleavage priming of the spike protein on coronavirus by angiotensin-converting enzyme-2 and furin. $J$ Biomol Struct Dyn 2020: 1-9.

63. Phua J, Weng L, Ling L, Egi M, Lim CM, Divatia JV et al. Intensive care management of coronavirus disease 2019 (COVID-19): challenges and recommendations. Lancet Respir Med 2020; 8: 506-517. 
64. Al-Tawfiq JA, Memish ZA. COVID-19 in the Eastern Mediterranean Region and Saudi Arabia: prevention and therapeutic strategies. Int J Antimicrob Agents 2020; 55: 105968.

65. Kandeel M, Al-Nazawi M. Virtual screening and repurposing of FDA approved drugs against COVID-19 main protease. Life Sci 2020; 251: 117627.

68. Mallineni SK, Innes NP, Raggio DP, Araujo MP, Robertson MD, Jayaraman J. Coronavirus disease (COVID-19): characteristics in children and considerations for dentists providing their care. Int J Paediatr Dent 2020; 30: 1-6.

67. Memish ZA, Ahmed QA, Schlagenhauf P, Doumbia S, Khan A. No time for dilemma: mass gatherings must be suspended. Lancet 2020; 395: 1191-1192.

68. Whiteside T, Kane E, Aljohani B, Alsamman M, Pourmand A. Redesigning emergency department operations amidst a viral pandemic. Am J Emerg Med 2020; S0735-6757(20)30262-X.

69. Yezli S, Khan A. COVID-19 social distancing in the Kingdom of Saudi Arabia: Bold measures in the face of political, economic, social and religious challenges. Travel Med Infect Dis 2020: 101692.
70. Atique S, Itumalla R. Hajj in the Time of COVID-19. Infect Dis Health 2020; S2468-0451(20)30023-7.

71. Petersen E, McCloskey B,. Hui D, Kock R, Ntoumi F, Memish Z. COVID-19 travel restrictions and the International Health Regulations - call for an open debate on easing of travel restrictions. Int J Infect Dis 2020; 94: 88-90.

72. World Health Organization. An R\&D blueprint for action to prevent epidemics. [Updated 2017. Cited 2020 April 28]. Available form URL: https://www.who.int/who-documentsdetail/an-r-d-blueprint-for-action-to-prevent-epidemics

73. Excler JL, Delvecchio CJ, Wiley RE, Williams M, Yoon IK, Modjarrad K, et al. Toward Developing a Preventive MERS-CoV Vaccine-Report from a Workshop Organized by the Saudi Arabia Ministry of Health and the International Vaccine Institute, Riyadh, Saudi Arabia, November 14-15, 2015. Emerg Infect Dis 2016; 22: e1-e7.

\section{Statistics}
Excerpts from the Uniform Requirements for Manuscripts Submitted to Biomedical Journals updated November 2003. Available from www.icmje.org

Describe statistical methods with enough detail to enable a knowledgeable reader with access to the original data to verify the reported results. When possible, quantify findings and present them with appropriate indicators of measurement error or uncertainty (such as confidence intervals). Avoid relying solely on statistical hypothesis testing, such as the use of $P$ values, which fails to convey important information about effect size. References for the design of the study and statistical methods should be to standard works when possible (with pages stated). Define statistical terms, abbreviations, and most symbols. Specify the computer software used. 